\title{
Isotopic niches of sympatric native and exotic fish species in a Neotropical floodplain
}

\author{
JULIANA S. PHILIPPSEN ${ }^{1}$, MARÍLIA HAUSER ${ }^{2}$ and EVANILDE BENEDITO ${ }^{1}$ \\ ${ }^{1}$ Programa de Pós-Graduação em Ecologia de Ambientes Aquáticos Continentais, \\ Universidade Estadual de Maringá, Av. Colombo, 5790, 87020-900 Maringá, PR, Brasil \\ ${ }^{2}$ Programa de Pós-Graduação da Rede de Biodiversidade e Biotecnologia da Amazônia Legal, Laboratório de \\ Ictiologia e Pesca, Universidade Federal de Rondônia, Rodovia BR 364, Km 9.5, 78900-000 Porto Velho, RO, Brasil \\ Manuscript received on June 5, 2014; accepted for publication on October 24, 2014
}

\begin{abstract}
This study investigated the isotopic niches of two fish species, one exotic and one native. It was hypothesized that these species would show little or no isotopic niche overlap. This hypothesis was tested with the isotopic niche concept and the trophic Layman's metrics. A considerable isotopic niche overlap was observed between the species, mainly for the exotic that showed the greater percentage of overlapping, indicating an interspecific competition for food resources. Layman's metrics also showed this species probably exploits a more specific array of food resources when compared with the native species. The native species probably has the ability to exploit a wider array of resources, highlighted by the higher values given for the Layman's metrics. The juveniles and adults of native species showed minor overlapping between the isotopic niches. This indicates that they have probably adopted different foraging strategies, minimizing intraspecific competition. Evidences that the exotic species explores a narrower range of resources and that the native species has a greater isotopic niche and possibly suffer less intraspecific competition, indicates that the native species can tolerate the presence of the exotic species and promote survival and maintenance of its population even under possible competition effects imposed by the exotic species.
\end{abstract}

Key words: competition, Hoplias sp1, Hoplias sp2, Layman's metrics, trophic interactions.

\section{INTRODUCTION}

The introduction of a non-native species in an ecosystem has great potential for presenting ecological risks if it is able to establish its population in the environment successfully (Gozlan and Newton 2009), resulting in possible harmful relationships with native species (Gozlan et al. 2010). Among aquatic animals, fish species are one of the most frequently introduced groups (Gozlan

Correspondence to: Juliana Strieder Philippsen

E-mail:ju_strieder@yahoo.com.br
2008). Non-native species have been introduced intentionally or not, through various human activities (Gozlan et al. 2010). The coexistence and interactions between species have been investigated by means of the niche concepts postulated by Grinnell, Elton and Hutchinson (Newsome et al. 2007, Colwell and Rangel 2009). Differences in niche breadth can be shown through morphological traits, trophic ecology and habitat use. The trophic niche breadth, calculated using dietary diversity, is the most frequently studied component of the 
niche space (Bearhop et al. 2004) and is of essential importance to understanding food web structure, resource use and trophic interactions in aquatic ecosystems (Chen et al. 2011). Moreover, these studies have practical applications when assessing possible impacts of exotic species on native species (Clarke et al. 2005, Pound et al. 2011).

Stable isotope analysis is becoming a very useful tool in studies that investigate the trophic ecology of native and exotic species (Cucherousset et al. 2012, Jackson et al. 2012). Recently, it has been argued that the isotopic ratios $\left({ }^{13} \mathrm{C}:{ }^{12} \mathrm{C}\right.$ and ${ }^{15} \mathrm{~N}:{ }^{14} \mathrm{~N}$ ) of the tissues of consumers could be used to represent the trophic niche of a particular species (Bearhop et al. 2004, Grey 2006), formalizing the isotopic niche concept (Newsome et al. 2007). These isotopic ratios can be used because it is known that these values reflect those of the species's diet (Jackson et al. 2011). Animals have an isotopic composition similar to their diet relative to $\delta^{13} \mathrm{C}$, due to its discrimination factor, which ranges from $0 \%$ to $1 \%$ along the food chain, while $\delta^{15} \mathrm{~N}$ varies from 3\%o to 5\% for each trophic level (Peterson and Fry 1987, Vander Zanden and Rasmussen 2001, Post 2002). Isotopic data are routinely presented in biplots $\left(\delta^{13} \mathrm{C}\right.$ on the $\mathrm{x}$-axis and $\delta^{15} \mathrm{~N}$ on the $\mathrm{y}$-axis), where isotopic values of the tissue of these animals can be represented on the isotopic space $(\delta)$, thus delineating the isotopic niche of a species (Newsome et al. 2007, Quevedo et al. 2009, Jackson et al. 2011). Individual variations in the $\delta^{13} \mathrm{C}$ and $\delta^{15} \mathrm{~N}$ values within a population can provide useful information on its trophic ecology (Bearhop et al. 2004, Layman et al. 2007).

Considering the need for a comprehensive analysis on patterns of use and partitioning of food resources in order to clarify how exotic species interact with native species (Vitule et al. 2012), this study aimed to characterize the isotopic niches of one exotic thraira Hoplias sp1 and one native thraira Hoplias sp2, fish species co-occurring in a Neotropical floodplain. Aspects of trophic structure were also investigated using Layman's metrics. It is already known that the population of the exotic species is established in the study area and that differences in ecomorphological, reproductive and population attributes have been reported for this species (Hauser and Benedito 2012). The main hypothesis tested was that these two species would exhibit no or little isotopic niche overlap and show greater differences in trophic metrics (Layman's metrics), which probably helps clarify how they can coexist in the same environment, even belonging to the same trophic guild.

\section{MATERIALS AND METHODS}

Samplings were conducted in the Upper Paraná River floodplain, which is approximately $200 \mathrm{~km}$ in length, between the mouth of the Paranapanema River and the Itaipu Reservoir $\left(22^{\circ} 00^{\prime}\right.$ to $23^{\circ} 00^{\prime} \mathrm{S}$; $53^{\circ} 00^{\prime}$ to $53^{\circ} 45^{\prime} \mathrm{O}$ ), this being the last dam-free stretch of the Upper Paraná River on Brazilian territory (Agostinho et al. 1994). Samples were taken at nine sampling sites: Baía River, Fechada Lake, Guaraná Lake (Baía subsystem), Paraná River, Garças Lake, Pau Véio Backwater (Paraná subsystem), Ivinheima River, Ventura Lake and Patos Lake (Ivinheima subsystem) during the Long Term Ecological Research project (PELD-Site 6) (State University of Maringá, Nupélia/PELD/CNPq, 2007) (Fig. 1).

Hoplias sp2 is a native species from the Upper Paraná River and Hoplias sp1 was introduced in this area after the formation of the Itaipu Reservoir and consequent flooding of Sete Quedas Falls, which formed a natural barrier between two hydrographic regions, and thus many endemic species of the lower stretch successfully colonized the Upper Paraná River (Pazza and Júlio Júnior 2003, Júlio Júnior et al. 2009, Hauser and Benedito 2012). Samplings of fish tissues were performed quarterly from March to December 2007, using gill nets with different mesh sizes (2.4 to $16 \mathrm{~cm}$ between opposite knots), exposed on the banks of the sampling sites for 24 hours and inspected every eight hours. After 


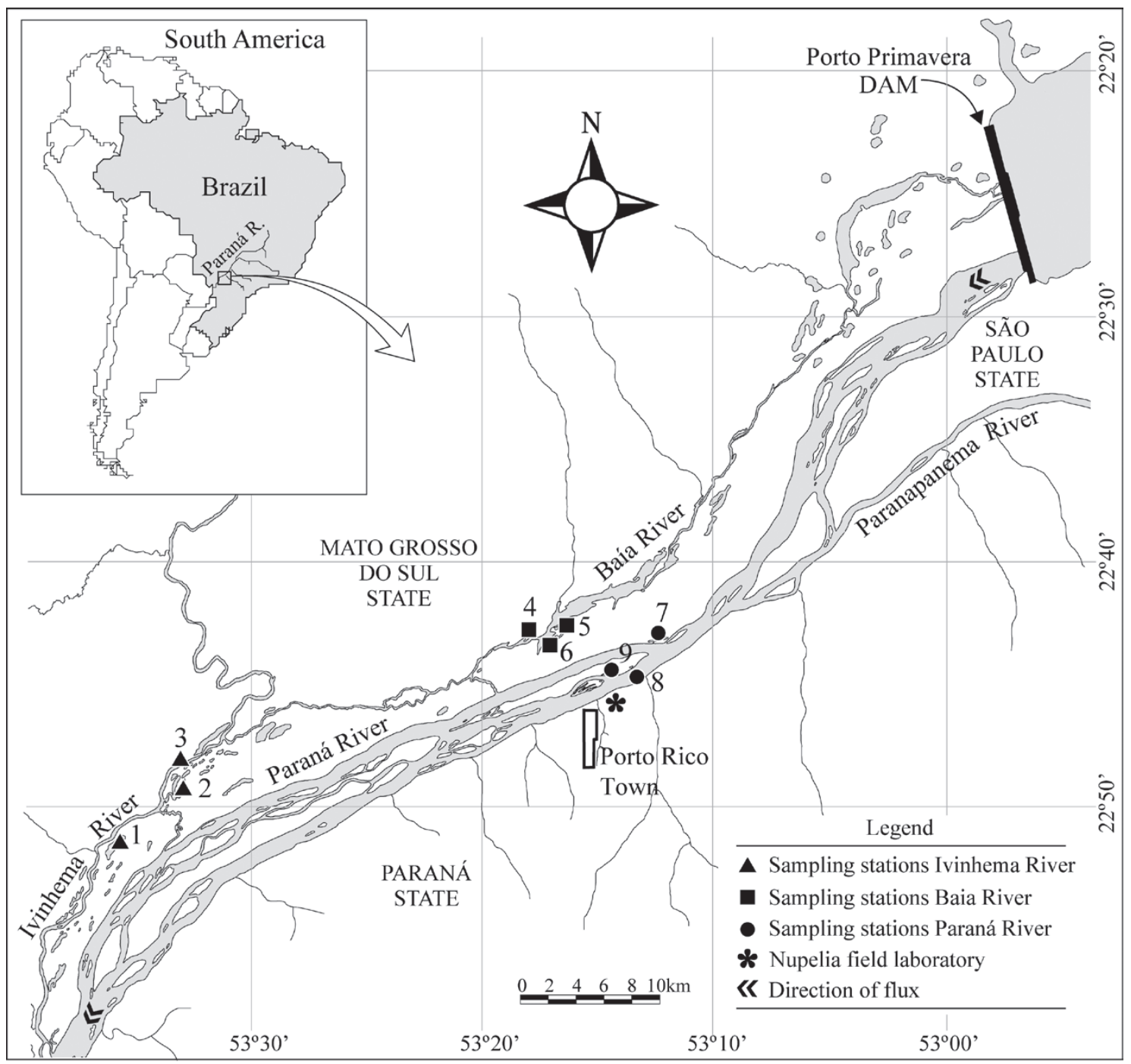

Figure 1 - Study area and location of the sampling sites in the Upper Paraná River floodplain: 1 - Paraná River, 2 - Garças Lake, 3 - Pau Véio Backwater, 4 - Baía River, 5 - Fechada Lake, 6 - Guaraná Lake, 7 - Ivinheima River, 8 - Patos Lake, 9 - Ventura Lake.

harvesting, individuals were anaesthetized and killed as recommended by AVMA (2007). Species were identified according to Graça and Pavanelli (2007) and deposited in the Fish Collection of the Research Nucleus in Limnology, Ichthyology and Aquaculture (Nupélia) of the State University of Maringá.

Periphyton, phytoplankton, aquatic macrophytes $\left(\mathrm{C}_{3}\right.$ and $\left.\mathrm{C}_{4}\right)$ and riparian vegetation were also sampled as representative of primary producers and used as baseline to calculate the trophic level of the studied fish species. They were obtained quarterly from March to
December, 2009. Leaves from riparian vegetation and aquatic macrophytes were collected using pruning shears. The periphyton was collected using petioles of macrophytes as substrate, and later a scalpel and brush was used in the laboratory to remove the periphytic algae onto a Petri dish. The phytoplankton were collected with a plankton net $(15 \mu \mathrm{m})$ and placed into $500 \mathrm{~mL}$-polyethylene flasks. These samples, as well as fish muscle samples, were processed in the laboratory, being subjected to oven drying and ground in a ball mill until a homogeneous fine powder was obtained. 
This material was sent in tin capsules to the UC Davis Facility, Stable Isotope Laboratory of the University of Davis, California, USA, for determination of the isotopic ratio in a mass spectrometer. The values obtained were expressed in delta notation $(\delta)$, and in parts per thousand (\%), relative to the international standard PeeDee Belemnite (PDB) for $\delta^{13} \mathrm{C}$ and atmospheric nitrogen for $\delta^{15} \mathrm{~N}$.

To investigate aspects of the trophic structure we applied metrics derived from isotopic values of $\delta^{13} \mathrm{C}$ and $\delta^{15} \mathrm{~N}$ of consumer's tissues, named Layman's metrics (Layman et al. 2007), adopting a Bayesian approach adapted by Jackson et al. (2011). We used the standard ellipse area (SEAc), the mean distance to centroid (CD), the variation of nitrogen $(\mathrm{Nr})$ and carbon $(\mathrm{Cr})$ and the standard deviation of the nearest neighbor distance (SDNND), described below. The metrics standard ellipse area corrected for sample size $(\mathrm{SEA} c)$ is calculated from the variance and covariance of the values of $\delta^{15} \mathrm{~N}$ and $\delta^{13} \mathrm{C}$, which accommodates $40 \%$ of the data and consequently reveals the core nucleus of the isotopic niche of a population, and is not expected to be sensitive to sample size. This is a measure of the core isotopic niche occupied by a population in the isotopic space.

These metrics were also calculated to compare the isotopic niche between juveniles and adults, and males and female shelping in the understanding of the intraspecific competition. Juveniles and adults were classified based on the standard length, according to Hauser and Benedito (2012). The metric of mean distance to centroid (CD) was used as a measure of trophic diversity of the population. CD was calculated as the average Euclidean distance of each individual of a population to the centroid $\delta^{13} \mathrm{C}-\delta^{15} \mathrm{~N}$ of this population. The variation of nitrogen $(\mathrm{Nr})$ and carbon $(\mathrm{Cr})$ corresponds to the distance between the highest and lowest values of $\delta^{15} \mathrm{~N}$ and $\delta^{13} \mathrm{C}$ within a population. These metrics indicate the total extent of nitrogen and carbon exploited by a population. A greater variation of $\delta^{15} \mathrm{~N}$ values among consumers indicates the species' ability to consume organisms occupying different trophic levels. High values of $\mathrm{Cr}$ suggest a higher diversity in the exploitation of basal carbon that can sustain a food chain.

The metric of standard deviation of the nearest neighbor distance (SDNND) was calculated as the standard deviation of Euclidean distances of each individual to the nearest neighbor individual in the isotopic space. This metric is a measure of the distribution/dispersal of individuals within an isotopic space: lower values of SDNND means smaller distance between individuals, i.e., the greater the packing of individuals within the isotopic space. The trophic level of the species and the trophic level of the juveniles and adults, and males and females was determined throughout the equation proposed by Vander Zanden et al. (1997):

$$
T=\frac{\left(N-N_{p s}\right)}{\Delta^{15} N}+1,
$$

where: $T$ is the estimation of the species trophic level, $N$ is the mean isotopic value of nitrogen for the species and $\Delta^{15} N$ is the mean isotopic value of nitrogen for the primary sources, and $\Delta^{15} N$ is the discrimination factor.

The constant indicates that the adopted baseline comprises the primary producers. As a discrimination factor, we adopted the mean value $\Delta^{15} \mathrm{~N}=2.3$ (standard deviation: 0.28) (McCutchan et al. 2003). An analysis of variance (one way ANOVA) was run in order to test the differences in the values of $\delta^{15} \mathrm{~N}$ among juveniles and adults, and females and males, within and between populations of $H . \operatorname{sp} 1$ and $H$. sp2. No spatial variation was detected in the analyses, therefore the observations were pooled for analysis and interpretation of data. Analyses were performed in $\mathrm{R}$ software (version 3.01, R Development Core Team 2013).

All procedures were carried out according to the practices for animal use and care under the control of an internal committee (Comissão de Ética no Uso de Animais-CEUA) of the Universidade Estadual de Maringá, Brazil. 


\section{RESULTS}

The isotopic niche area occupied by $H$. sp2 (5.2\%o) is higher than the SEAc of $H$. sp1 (3.8\%o), and the percentage of niche overlap between them was $26.5 \%$ and $35.8 \%$, respectively (Fig. 2). The SEA $c$ was higher for juveniles than for adults of $H$. sp1 (Fig. 3) and $H$. sp2 (Fig. 4). The area of overlap was $46.5 \%$ and $27.8 \%$ between adults and juveniles of $H$. sp1, respectively, and $31.3 \%$ for adults and $21.3 \%$ for juveniles for $H$. $\mathrm{sp} 2$. There was a high level of isotopic niche overlap between males (42.2\%) and females (40.3\%) for $H$. sp1 (Fig. 5), and 41\% for both sexes in $H$. sp2 (Fig. 6).

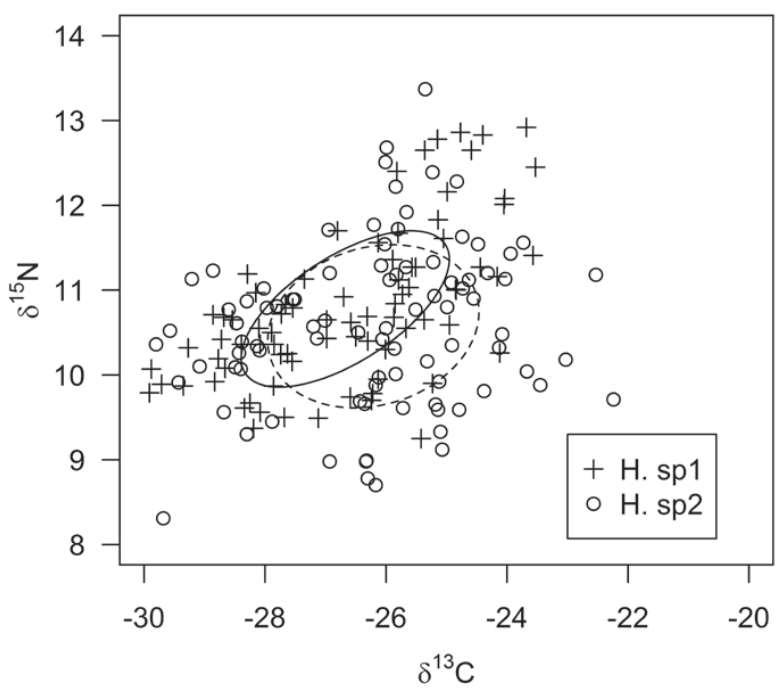

Figure 2 - Isotopic niche areas of exotic $(H . \mathrm{sp} 1)$ and native (H. sp2). The lines represent the SEAc, which represents the core nucleus of the isotopic niche of a population (solid line and black points represents the exotic species; dashed line and open points represent the native one).

In relation to the Layman's metrics the native species showed higher values than the exotic. This means that the native (i) has a higher dietary diversity (measured as the $\mathrm{CD}$ metric); (ii) exploits a great variety of basal resources (Cr measure) and great diversity of individuals from different trophic levels ( $\mathrm{Nr}$ measure); (iii) has higher individual dispersion in isotopic space within its population, compared to the exotic species (Table I).

The mean values of $\delta^{13} \mathrm{C}$ and $\delta^{15} \mathrm{~N}$ and the trophic level for each species and for adult and

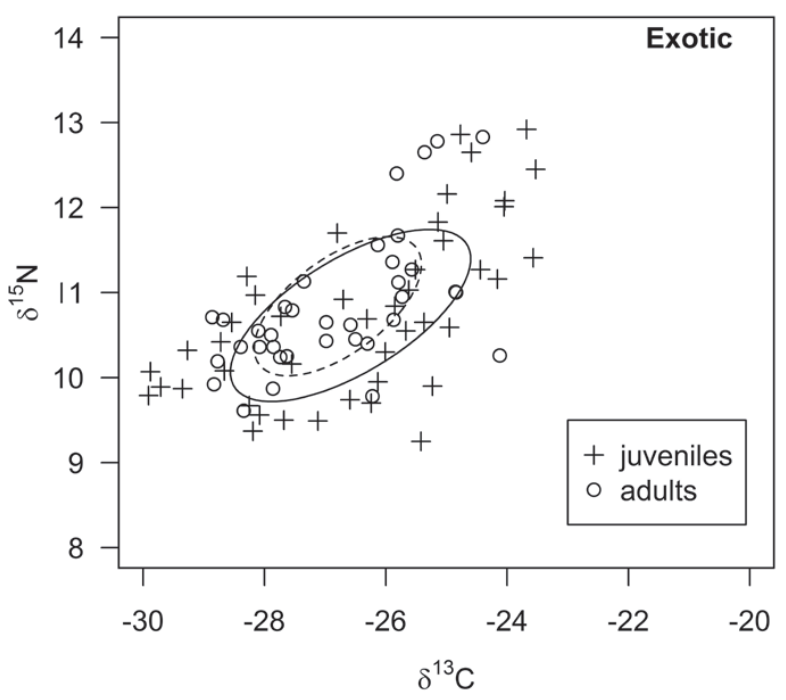

Figure 3 - Isotopic niches overlap of juveniles and adults of exotic species. The lines represent the SEAc, which represents the core nucleus of the isotopic niche of a population (solid lines: juveniles and dashed lines: adults).

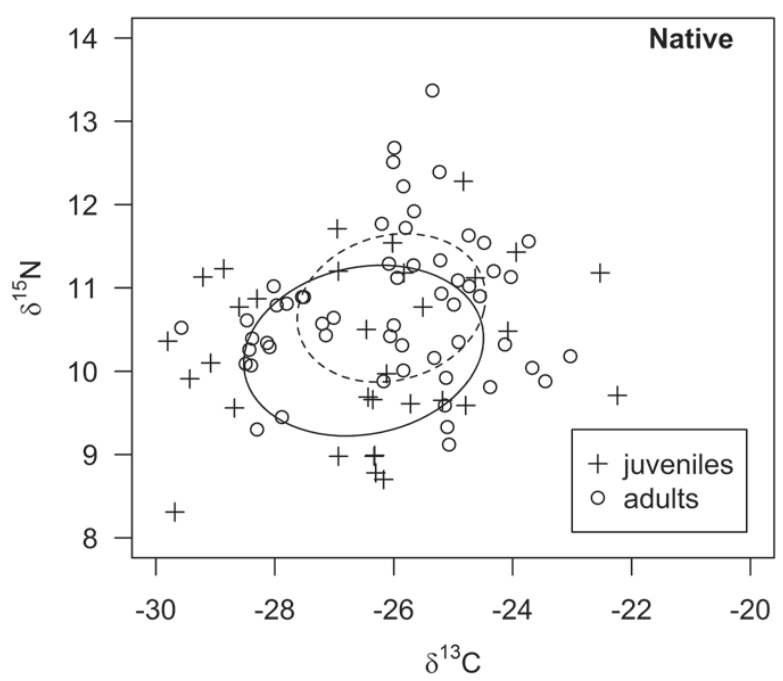

Figure 4 - Isotopic niches overlap of juveniles and adults of the native species. The lines represent the SEAc, which represents the core nucleus of the isotopic niche of a population (solid lines: juveniles and dashed lines: adults).

juveniles, and males and females of $H$. sp1 and $H$. sp2 are presented in table II. The results of the ANOVA gave no evidence of differences between juveniles and adults of $H$. sp1 (ANOVA, $\mathrm{F}_{1,79}=$ $0.524, \mathrm{P}>0.05$ ), whereas a significant difference was found between juveniles and adults of $H$. sp2 relative to the values of $\delta^{15} \mathrm{~N}$ (ANOVA, $\mathrm{F}_{1,86}=7.203, \mathrm{P}<$ 


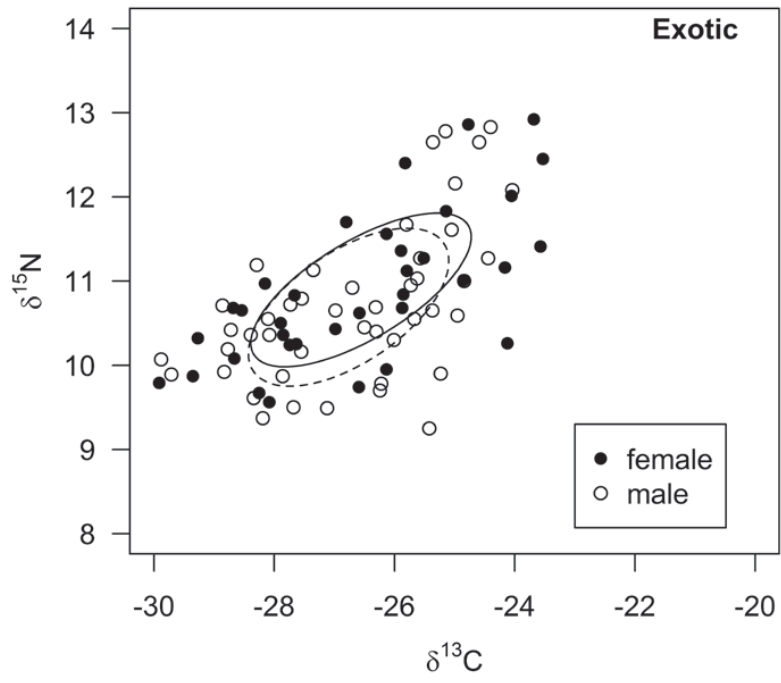

Figure 5 - Isotopic niches overlap of females and males of exotic species. The lines represent the SEAc, which represents the core nucleus of the isotopic niche of a population (solid lines: females and dashed lines: males).

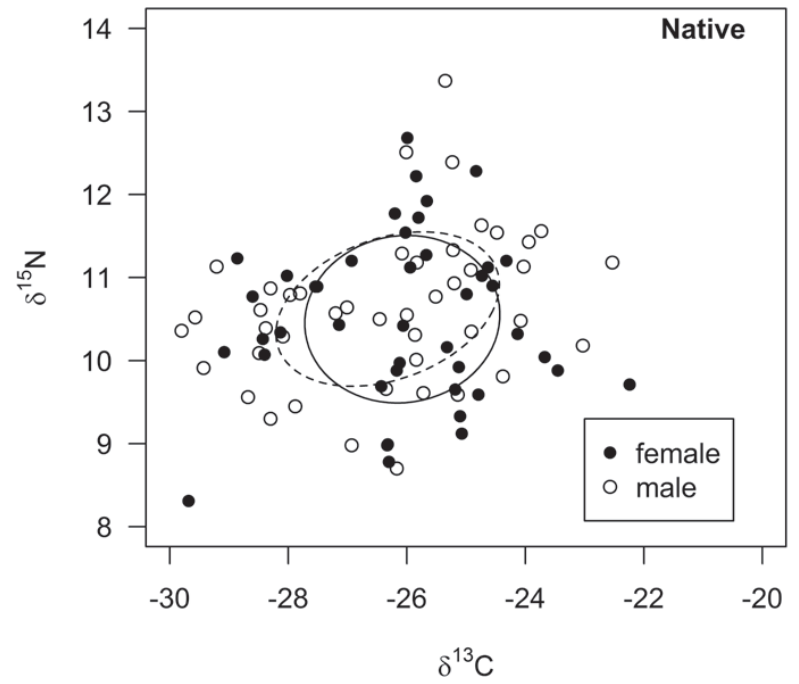

Figure 6 - Isotopic niches overlap of females and males of the native species. The lines represent the SEAc, which represents the core nucleus of the isotopic niche of a population (solid lines: females and dashed lines: males).

TABLE I

Layman's metrics for Hoplias sp1(exotic thraira) and Hoplias sp2 (native thraira) in the Upper Paraná River floodplain. The Bayesian credibility intervals (BCI) for the posterior distributions, means and standard deviation (S.D.) are shown.

\begin{tabular}{cccccccc}
\hline BCI & $2.5 \%$ & $25 \%$ & $50 \%$ & $75 \%$ & $97.5 \%$ & mean & S.D. \\
\hline Exotic (n=81) & & & & & & & \\
Nr & 0.5178 & 0.8577 & 1.0458 & 1.2373 & 1.6191 & 1.0507 & 0.2808 \\
Cr & 0.2168 & 0.5965 & 0.8203 & 1.0681 & 1.5641 & 0.8411 & 0.3458 \\
CD & 0.3610 & 0.4830 & 0.5535 & 0.6322 & 0.8121 & 0.5628 & 0.1153 \\
SDNND & 0.0065 & 0.0742 & 0.1624 & 0.2756 & 0.5153 & 0.1887 & 0.1405 \\
\hline Native (n=88) & & & & & & & \\
Nr & 1.1624 & 1.6145 & 1.8401 & 2.0574 & 2.5170 & 1.8387 & 0.3392 \\
Cr & 0.7806 & 1.2124 & 1.4326 & 1.6673 & 2.1249 & 1.4408 & 0.3417 \\
CD & 0.7422 & 0.9098 & 0.9959 & 1.0825 & 1.2562 & 0.9968 & 0.13 \\
SDNND & 0.0063 & 0.0778 & 0.1695 & 0.2845 & 0.5222 & 0.1939 & 0.1427 \\
\hline
\end{tabular}

TABLE II

Mean values of $\delta^{13} \mathrm{C}$ and $\delta^{15} \mathrm{~N}$ and the trophic position for each species and for adult and juveniles, males and females of exotic (H. sp1) and native (H. sp2) (S.D.: standard deviation; TP: trophic position).

\begin{tabular}{cccccc}
\hline & Mean $\delta^{13} \mathrm{C}$ & $\mathrm{sd}$ & Mean $\delta^{15} \mathrm{~N}$ & S.D. & TP \\
\hline Exotic & -26.67 & 1.71 & 10.78 & 0.92 & 3.75 \\
juveniles & -26.58 & 1.96 & 10.73 & 1.00 & 3.72 \\
adults & -26.79 & 1.36 & 10.84 & 0.81 & 3.77 \\
female & -26.56 & 1.81 & 10.90 & 0.90 & 3.79 \\
male & -26.76 & 1.65 & 10.69 & 0.93 & 3.71 \\
\hline Native & -26.21 & 1.73 & 10.57 & 0.96 & 3.65 \\
juveniles & -26.51 & 1.98 & 10.25 & 1.01 & 3.52 \\
adults & -26.04 & 1.57 & 10.76 & 0.88 & 3.73 \\
female & -26.08 & 1.63 & 10.50 & 1.00 & 3.62 \\
male & -26.34 & 1.84 & 10.65 & 0.92 & 3.68 \\
\hline
\end{tabular}


0.05). A significant difference between juveniles of $H$. sp1 and $H$. sp2 was also detected (ANOVA, $\mathrm{F}_{1,75}$ $=4.727, \mathrm{P}<0.05)$, but no significant differences were verified for adults (ANOVA, $\mathrm{F}_{1,90}=0.2817, \mathrm{P}>$ $0.05)$. No intraspecific significant differences could be observed in respect of gender among and between the species studied ( $H$. sp1: ANOVA, $\mathrm{F}_{1,79}=1.157$, $\mathrm{P}>0.05 ; H$. sp2: ANOVA, $\mathrm{F}_{1,86}=0.6344, \mathrm{P}>0.05$ ) (females: ANOVA, $\mathrm{F}_{1,76}=3.7326, \mathrm{P}>0.05$, males: ANOVA, $\left.\mathrm{F}_{1,89}=0.0621, \mathrm{P}>0.05\right)$.

\section{DISCUSSION}

Recently some studies have indicated an overlapping of isotopic niches between native and exotic species (Mercado-Silva et al. 2009, Olsson et al. 2009, Ruokonen et al. 2012). In this study, this overlapping was also observed between the exotic and the native species. Jackson et al. (2012) suggest that there is an inverse relationship between the isotopic niche space occupied by one species and the degree of interspecific competition that it experiences. So, a bigger isotopic niche space could reflect a smaller competition degree. It was found that $H$. sp2 exhibits a higher isotopic niche space than $H$. sp1, so the former could probably suffer less competition compared to $H$. sp1. Furthermore, the native species showed higher values for the Layman's metrics than the exotic one, which helps to corroborate the idea that the native species could explore more variable food sources and possibly experiences less competition than the exotic. The exotic species is probably being subject to higher competition pressure once it has a greater percentage of overlapping area in its isotopic niche space. The smaller isotopic niche area that the exotic species exhibited, suggests that it probably exploits a more specific array of resources than the native, corroborating Bolnick et al. (2007), who affirm that exotic species can exploit a narrower range of resources, which are not exploited by its conspecifics.

In relation to intraspecific variations in the use of resources, populations can be formed of ecologically heterogeneous individuals that use subsets of resources available in the environment (Svanbäck and Bolnick 2007). In this context, individuals may use different resources by being of different sexes and age groups (Box et al. 2010, Borrel et al. 2011). When observing the overlap in the isotopic niche between juveniles and adults and between males and females of $H$. sp 1 and $H$. sp2, a high level of overlap between sexes for both species was found. With regards to age groups, the overlapping was greater for adults within each species. Besides that, adults presented a lower SEAc than juveniles, evidencing that the latter seem to be more generalist and adults more specialist, for both $H$. sp1 and $H$. sp2.

Some researchers have demonstrated that changes in the diet during the ontogenetic development may result in alterations in trophic relationships both at population and species level (Nakazawa et al. 2010). The native H. sp2 showed a significant difference in $\delta^{15} \mathrm{~N}$ values between juveniles and adults although they are in the same trophic level. Besides that, they showed less overlap in the isotopic niche space than the exotic species. In this way, it is possible that $H$. sp2 may have adopted distinct foraging strategies between juveniles and adults, to possibly minimize intraspecific competition and favouring population survival and maintenance, even with the possible competition caused by the presence of the exotic species. In conclusion, although these species could be experiencing competition to a certain degree, showing substantial isotopic niche overlap, the results indicate that they could co-occur in this environment without drastic population damage to the native species allowing $H$. sp2 to maintain a stable population over time.

\section{ACKNOWLEDGMENTS}

The authors thank R. Mazzoni and W. Júnio da Graça for valuable suggestions on earlier versions of this manuscript and PEA/NUPÉLIA for logistical support. J.S. Philippsen and M. Hauser acknowledges 
to national funding agency Coordenação de Aperfeiçoamento de Pessoal de Nível Superior (CAPES) while E. Benedito acknowledges to Conselho Nacional de Desenvolvimento Científico e Tecnológico (CNPq) for providing scholarships.

\section{RESUMO}

Este estudo investigou o nicho isotópico de duas espécies de peixes, uma exótica e outra nativa. A hipótese testada foi a de que estas espécies teriam pouca ou nenhuma sobreposição de nicho isotópico. Esta hipótese foi testada adotando o conceito de nicho isotópico e as métricas tróficas de Layman. Uma considerável sobreposição de nicho isotópico foi observada entre as duas espécies, principalmente para a exótica que teve maior porcentagem de sobreposição,indicandouma competiçãointerespecífica por recursos alimentares. As métricas de Layman também mostraram que esta espécie provavelmente explora um conjunto de recursos alimentares mais específico quando comparada a espécie nativa. A espécie nativa provavelmente tem a habilidade de explorar um conjunto de recursos mais amplo, demonstrado pelos altos valores que exibiu para as métricas de Layman. Jovens e adultos da espécie nativa mostraram menor sobreposição nos nichos isotópicos. Isto indica que eles provavelmente adotaram estratégias de forrageamento diferentes, minimizando a competição intraespecífica. Evidências de que a espécie exótica explora um conjunto de recursos mais restrito e que a espécie nativa tem um maior nicho isotópico e possivelmente sofre menor competição intraespecífica, indica que a espécie nativa pode tolerar a presença da espécie exótica, promovendo a manutenção e sobrevivência de sua população mesmo sob um possível efeito de competição imposto pela espécie exótica.

Palavras-chave: competição, Hoplias sp1, Hoplias sp2, métricas de Layman, interações tróficas.

\section{REFERENCES}

Agostinho AA, JÚlio JÚNior HF AND Petrere Junior M. 1994. Itaipu Reservoir (Brazil): impacts of the impoundment on the fish fauna and fisheries. In: Cowx IG (Ed), Rehabilitation of freshwater fisheries, Osney Mead, Oxford: Fishing News Books, p. 171-184.
AVMA. 2007. Guidelines on Euthanasia. Formerly Report of the AVMA Panel on Euthanasia.

BeARHop S, Waldron S, Fuller RA, Macleod H AND ADAMS CE. 2004. Determining trophic niche width: a novel approach using stable isotope analysis. J Anim Ecol 73: 1007-1012.

BOLNICK DI, SVANBÄCK R, ARAÚJO MS AND PERSSON L. 2007. Comparative support for the niche variation hypothesis that more generalized populations are also more heterogeneous. Proc Natl Acad Sci USA 104: 10075-10079.

Borrel A, Aguilar A, Gazo M, Kumarran RP AND CARDONA L. 2011. Stable isotope profiles in whale shark (Rhincodontypus) suggest segregation and dissimilarities in the diet depending on sex and size. Environ Biol Fish 92: $559-567$.

Box A, Deudero S, Blanco A, Grau AM and Riera F. 2010. Differences in $\delta^{13} \mathrm{C}$ and $\delta^{15} \mathrm{~N}$ stable isotopes in the pearly razor fish Xyrichtys novacula related to the sex, location and spawning period. J Fish Biol 76: 2370-2381.

Chen G, Wu Z, Gu B, LiU D, Li X AND WANG Y. 2011. Isotopic niche overlap of two planktivorous fishes in southern China. Limnology 12: 151-155.

Clarke LR, Vidergar DT AND BenNett DH. 2005. Stable isotopes and gut content show diet overlap among native and introduced piscivorous in a large oligotrophic lake. Ecol Freshw Fish 14: 267-277.

COLWELl RK AND RANGEL TF. 2009. Hutchinson's duality: the once and future niche. Proc Natl Acad Sci USA 106 19651-19658.

Cucherousset J, Bouletreau S, Martino A, Roussel JM AND SANTOUL F. 2012. Using stable isotope analyses to determine the ecological effects of non-native fishes. Fish Manage Ecol 19: 111-119.

GOZLAN RE. 2008. Introduction of non-native freshwater fish: is it all bad? Fish Fish 9: 106-115.

GOzLAN RE AND NEWTON AC. 2009. Biological invasions: benefits versus risks. Science 324: 1015-1016.

GOZLAN RE, BRITTON JR, CowX I AND COPP GH. 2010. Current knowledge on non-native freshwater fish introductions. J Fish Biol 76: 751-786.

GraÇA WJ AND PaVAnelli CS. 2007. Peixes da planície inundação do alto rio Paraná e áreas Adjacentes, Maringá: Eduem, p. 241.

GREY J. 2006. The use of stable isotope analyses in freshwater ecology: current awareness. Pol J Ecol 54: 563-584.

Hauser M ANd Benedito E. 2012. Species of the Hoplias aff. malabaricus complex (Characiformes: Erythrinidae): an investigation of coexistence in a Neotropical floodplain. Rev Bras Zool 29: 59-69.

JACKSON AL, INGER R, PARNELL AC AND BEARHOP S. 2011. Comparing isotopic niche widths among and within communities: SIBER - Stable isotope Bayesian ellipses in R. J Anim Ecol 80: 595-602.

JACKSON MC, DONOHUE I, JACKSON A, BRITTON JR, HARPER DM AND GREY J. 2012. Population-level metrics of trophic structure based on stable isotopes and their application to invasion ecology. PLoS ONE 7: 1-12. 
JÚlio JúNIOR HF, DEI Tós C, AgOSTINHO AA AND PAVANELlI C. 2009. A massive invasion of fish after eliminating a natural barrier in the upper rio Paraná basin. Neotrop Ichthyol 7: 709-718.

LAYMAn CA, ARrington DA, Montaña CG AND Post DM. 2007. Can stable isotope ratios provide for communitywide measures of trophic structure? Ecology 88: 42-48.

McCutchan JH, Lewis MW, Kendall C AND MCGRath C. 2003. Variation in trophic shift for stable isotope ratios of carbon, nitrogen and sulfur. Oikos 102: 378-390.

Mercado-Silva N, Helmus MR AND VANDER Zanden MJ. 2009. The effects of impoundment and non-native species on a river food web in Mexico's Central plateau. River Res Appl 25: 1090-1108.

NAKAZAWA T, SAKaI Y, HSIEH C, KoITABashi T, TAYASU I, YAMAMURA N AND OKUDA N. 2010. Is the relationship between body size and trophic niche position timeinvariant in a predatory fish? First stable isotope evidence. PLOS ONE 5: 1-5.

Newsome SD, Martinez Del Rio C, Bearhop S AND PhILIPPS DL. 2007. A niche for isotopic ecology. Front Ecol Environ 5: 429-436.

Olsson K, StenRoth P, Nyström P AND GRANÉLi W. 2009. Invasions and niche width of an introduced crayfish differ from a native crayfish? Freshwater Biol 54: 1731-1740.

PAZZA R AND JÚLIO JÚNIOR HF. 2003. Occurrence of three sympatric cytotypes of Hoplias malabaricus (Pisces, Erythrinidae) in the upper Paraná riverfoodplain (Brazil). Cytologia 68: 159-163.

Peterson BJ AND Fry B. 1987. Stable isotopes in ecosystem studies. Annu Rev Ecol Syst 18: 293-320.

PosT DM. 2002. Using stable isotopes to estimate trophic position: models, methods, and assumptions. Ecology 83: 703-718.
Pound KL, Nowlin WH, Huffman DG AND BonNer TH. 2011. Trophic ecology of a nonnative population of suckermouth catfish (Hypostomus plecostomus) in a Central Texas spring-fed stream. Environ Biol Fish 90: 277-285.

QUEVEDO M, SVANBÄCK RAND EKLÖV P. 2009. Intrapopulation niche partitioning in a generalist predator limits food web connectivity. Ecology 90: 2263-2274.

R DEVELOPMENT CORE TEAM. 2011. http:/www.Rproject.org. R: A language and environment for statistical computing. R Foundation for Statistical Computing, Vienna, Austria. ISBN 3-900051-07-0.

RuOKONEN TJ, KarJalainen J, KiLJUNEN M, PURSIAINEN M AND HÄMÄLÄINEN H. 2012. Do introduced crayfish affect benthic fish in stony littoral habitats of large boreal lakes. Biol Invasions 14: 813-825.

SVANBÄCK R AND BOLNICK DI. 2007. Intraspecific competition drives increased resource use diversity within a natural population. Proc R Soc B 274: 839-844.

VANDER ZANDEN MJ, CABANA G AND RASMUSSEN JB. 1997. Comparing trophic position of calculated using stable nitrogen isotope ratios $\left(\delta^{15} \mathrm{~N}\right.$ and literature dietary data). Can J Fish Aquat Sci 54: 1142-1158.

VANDER ZANDEN MJ AND RASMUSSEN JB. 2001. Variation in $\delta^{15} \mathrm{~N}$ and $\delta^{13} \mathrm{C}$ trophic fractionation: implications for aquatic food web studies. Limnol Oceanogr 46: 2061-2066.

VITULE JRS, SKóRA F AND ABILHOA V. 2012. Homogenization of freshwater fish faunas after the elimination of a natural barrier by a dam in Neotropics. Divers Distrib 18: 111-120. 
